\title{
DETERMINAN INTERNET FINANCLAL REPORTING DI INDONESIA
}

\author{
Oleh: \\ Tita Djuitaningsih \\ (Dosen Program Studi Akuntansi Fakultas Ekonomi dan Ilmu Sosial Universitas Bakrie) \\ Pinandito \\ (Alumni Program Studi Akuntansi Fakultas Ekonomi dan Ilmu Sosial Universitas Bakrie)
}

\begin{abstract}
The objective of this study is to examine the effect of size, profitability, leverage, price to book value and board size on internet financial reporting (IFR). Population of this study is financial firms that registered in Bursa Efek Indonesia in 2010. After going through purposive sampling process, 43 sample firm is selected. This study using multiple regression to examine the effect of size, profitability, leverage, and price to book value on IFR. Before doing a regression test, there is test named assumption classic test, it is consist of normality test, multicolinearity test and heteroskedasticity test. The result of the regression test shows that size positively influence IFR. Profitability, leverage, and price to book value are not influence IFR.
\end{abstract}

Keywords: Internet financial reporting, size, profitability, leverage, price to book value.

\section{Latar Belakang}

Internet merupakan salah satu penemuan teknologi terbesar yang sangat mendukung perkembangan komunikasi (Xiao, Yang \& Chow, 2002). Perkembangan yang cepat dalam dunia internet membawa perubahan dalam penyebaran informasi. Banyak perusahaan telah menggunakan internet sebagai alat komunikasi untuk menyediakan informasi mengenai perusahaan, termasuk penyebarluasan informasi keuangan (Chariri \& Lestari, 2005). Internet dapat menyediakan cara yang lebih baik dan efektif untuk mengkomunikasikan informasi keuangan maupun non keuangan. Penggunaan internet untuk sarana pelaporan keuangan bersifat sukarela, bukan merupakan sesuatu keharusan (Turel, 2010).

Terdapat beberapa karakteristik utama dari internet, pertama adalah informasi yang dapat diakses hampir setiap saat dan di mana pun serta secara umum dalam biaya yang rendah. Kedua, internet dapat memberikan informasi yang up-to-date. Ketiga, sedikit keterbatasan atas ketersediaan data. Keempat, informasi dapat mencakup presentasi dan multimedia yang dinamis. Kelima, terdapat kemungkinan informasi yang interaktif antara permintaan dan penawaran (Wagenhofer, 2003). Xiao et al. (2002) menyatakan bahwa internet menawarkan berbagai kemungkinan kepada perusahaan untuk menyajikan informasi keuangan dengan kuantitas yang lebih banyak, biaya yang lebih murah, dan bisa menjangkau para pemakai secara luas tanpa halangan geografis.

Hanifa dan Rashid (2005) menyatakan bahwa saat ini penyajian informasi perusahaan sedang dalam periode perpindahan dari paper-based reporting system ke paper-less reporting system. Pelaporan keuangan melalui internet adalah suatu bentuk upaya manajemen untuk mengurangi asimetri informasi sehinga investor akan mengapresiasi usaha manajer (Rahman, 2011). Ashbaugh, Johnstone dan Warfield (1999) menyatakan bahwa internet dipandang sebagai salah satu media pelaporan yang penting, sehingga informasi tentang kinerja perusahaan dapat dijangkau oleh seluruh investor, kreditor, pemegang saham, dan analis secara global. Perusahaan pun menciptakan cara 
baru untuk menyebarluaskan informasi dan berkomunikasi dengan investor melalui dunia maya. Hunter dan Smith (2007) menjelaskan bahwa internet financial reporting (IFR) merujuk pada penggunaan website perusahaan dalam menyebarkan informasi tentang performa keuangan perusahaan.

Penerapan IFR pada perusahaan dipercaya sebagai bentuk transparansi perusahaan (Deller et al., 1999; Silva \& Alves, 2004; Silva \& Chirtensen, 2004). Rahman (2011) menyatakan bahwa transparansi dilakukan oleh perusahaan melalui pengungkapan yang lebih luas menunjukkan bahwa perusahaan melakukan bisnis dengan dengan tata kelola yang baik (good corporate governance). Agustina (2009) menyatakan bahwa IFR adalah teknologi baru yang telah diperkenalkan dalam area pelaporan keuangan dan merupakan fenomena yang berkembang pesat baru-baru ini. Beberapa perusahaan mempublikasikan informasi keuangan melalui internet, terutama yang go public. Laporan keuangan yang disampaikan dapat berformat Hyper Text Markup Language (HTML), dokumen yang berbentuk Portable Data Format (PDF), Microsoft Excel maupun Microsoft Word.

Financial Accounting Standards Board (2000) mendeskripsikan IFR melalui konten dan presentasi. Konten keuangan dalam website perusahaan biasanya mengandung pengungkapan sukarela, seperti stock quotes, press releases, financial history, dan lainnya, sebagai tambahan atas persyaratan tradisional yang dibutuhkan, seperti laporan keuangan kuartalan dan tahunan. Bentuk presentasi pun beragam, mulai dari format yang sama seperti printed annual report hingga bentuk dinamis seperti penambahan efek suara dan video untuk meningkatkan tampilan serta kemudahan untuk dibaca dan dimengerti.

Asbaugh et al. (1999) menjelaskan bahwa terdapat beberapa keuntungan potensial jika perusahaan menerapkan IFR daripada praktek pengungkapan sukarela lainnya. Pertama, perusahaan dapat mengurangi biaya penyebaran informasi. Pembuat keputusan dapat menggunakan website sebuah perusahaan untuk mendapatkan informasi keuangannya sehingga perusahaan dapat menghemat biaya mencetak atau mengirimkan laporan keuangan untuk kepentingan pembuat keputusan. Kedua, IFR dapat memenuhi permintaan stakeholder mengenai informasi perusahaan tanpa batas waktu dan wilayah. Ketiga, IFR dapat memfasilitasi konsumen untuk mengetahui informasi spesifik perusahaan untuk analisis lebih lanjut dari pembuat keputusan dari latar belakang yang berbeda melalui hyperlinks dan transfer data. Keempat, IFR dapat meningkatkan pengungkapan keuangan perusahaan melalui suplementasi atas praktek penyebaran informasi secara tradisional.

Berdasarkan uraian di atas, secara teori perusahaan akan mendapatkan keuntungan apabila menerapkan IFR, namun belum semua perusahaan menyajikan laporan keuangan dalam website mereka (Xiao et al., 2002). Lai, Lin dan Lee (2007) menyatakan bahwa belum ada regulasi internasional yang mengatur mengenai IFR. Oleh karena itu, kualitas informasi yang ditampilkan di website perusahaan beragam antara yang satu dengan yang lainnya (Rahman, 2011). Hal ini menggambarkan bahwa terdapat berbagai faktor yang memengaruhi perusahaan dalam penerapan IFR. Moradi, Salehi dan Arianpoor (2011) menguatkan dugaan ini dengan argumen bahwa pengaplikasian IFR pada perusahaan dipengaruhi oleh faktor-faktor yang beragam seperti sosial, kultural, institusional, dan hukum.

Hasil penelitian Almilia (2009) menunjukkan bahwa hanya 62\% perusahaan listed di Bursa Efek Indonesia (BEI) yang mempunyai website untuk mempublikasikan beberapa informasi tentang kondisi keuangan dan non keuangan perusahaan. Penelitian ini menemukan bahwa ukuran perusahaan dan profitabilitas berpengaruh positif terhadap IFR. Chariri et al. (2005) menemukan bahwa faktor-faktor seperti ukuran perusahaan, likuiditas, leverage, reputasi auditor dan umur listing perusahaan berpengaruh terhadap 
praktek IFR pada perusahaan non keuangan yang terdaftar di Bursa Efek Jakarta. Aziz, Arifin dan Mohamed (2009) menemukan bahwa penjualan perusahaan dan presentase free float berpengaruh positif terhadap kualitas skor IFR di perusahaan yang terdaftar di Bursa Malaysia. Pervan (2006) melakukan penelitian di Kroasia dan Slovenia dengan hasil yang berbeda untuk setiap jenis industri. Penelitian tersebut menemukan bahwa ukuran perusahaan, profitabilitas, jumlah pemegang saham, dan jumlah transaksi di pasar saham berpengaruh positif terhadap skor IFR di Kroasia. Akan tetapi hasil berbeda ditemukan di Slovenia, proporsi kapitalisasi pasar dan rasio market to book value dari saham berpengaruh positif terhadap IFR. Xiao et al., (2004) meneliti pengaruh corporate governance terhadap IFR. Penelitian ini menemukan bahwa struktur kepemilikan perusahaan seperti kepemilikan agen pemerintah dan kepemilikan perseorangan berpengaruh positif terhadap IFR. Kelton dan Yang (2004) menemukan bahwa perusahaan dengan weak stakeholder rights dan persentase direktur independen yang lebih tinggi berpengaruh positif terhadap IFR. Trabelsi, Labelle dan Dumontier (2008) melakukan penelitian praktek IFR di Kanada dengan sampel sejumlah 108 perusahaan yang terdaftar di Toronto Stock Exchange. Penelitian ini menemukan bahwa share turnover, biaya riset dan pengembangan, performa perusahaan, ukuran perusahaan, dan asimetri informasi berpengaruh positif terhadap IFR. Ezat dan El-Masry (2008) meneliti IFR timeliness pada 50 perusahaan Mesir yang terdaftar di Cairo and Alexandria Stock Exchange (CASE). Penelitian tersebut menemukan bahwa ukuran perusahaan, likuiditas, struktur kepemilikan, tipe aktivitas jasa, komposisi direksi dan ukuran dewan direksi berpengaruh positif terhadap IFR timeliness.

Berdasarkan hasil penelitian terdahulu yang telah diuraikan di atas, terlihat bahwa penelitian tentang IFR masih menunjukkan hasil yang tidak konsisten, sehingga perlu dilakukan pengujian lebih lanjut. Penelitian ini merupakan replikasi dari penelitian Almilia (2009), dengan memasukkan market to book value (Pervan, 2006) yang selanjutnya disebut dengan price to book value (PBV). Pervan (2006) menjelaskan bahwa apabila suatu perusahaan telah menjual saham kepada publik, maka akan ada permintaan yang lebih banyak atas informasi keuangan dan non-keuangan perusahaan. Investor memberi nilai lebih kepada perusahaan yang lebih transparan, mengingat risiko yang ditanggung akan lebih kecil.

Penelitian ini menggunakan seluruh perusahaan sektor keuangan yang terdaftar di BEI. Almilia (2009) menyatakan bahwa sektor keuangan lebih teregulasi. Perusahaan keuangan non-LQ 45 diikutsertakan sebagai sampel merupakan usaha untuk memperluas ruang lingkup penelitian sebelumnya.

Berdasarkan latar belakang yang telah diuraikan, perumusan masalah dalam penelitian ini adalah: apakah ukuran perusahaan, profitabilitas, leverage, dan price to book value (PBV) berpengaruh terhadap IFR? Penelitian ini diharapkan dapat menambah literatur mengenai perkembangan teori dan pengetahuan di bidang akuntansi yang berkaitan dengan faktor- faktor yang memengaruhi IFR di Indonesia. Bagi dunia praktis penelitian ini dapat digunakan sebagai bahan pertimbangan untuk memanfaatkan IFR dengan tujuan untuk meningkatkan kualitas pengungkapan pelaporan finansial maupun non-finansial sehingga dapat meningkatkan komunikasi dengan stakeholders.

\section{Kerangka Pemikiran}

Di dalam Pernyataan Standar Akuntansi Keuangan (PSAK) No. 1 tentang Penyajian Laporan Keuangan dinyatakan bahwa laporan keuangan adalah suatu penyajian terstruktur dari posisi keuangan dan kinerja keuangan suatu entitas. Tujuan laporan keuangan adalah memberikan informasi mengenai posisi keuangan, kinerja keuangan, dan arus kas entitas yang bermanfaat bagi sebagian besar kalangan pengguna laporan 
keuangan dalam pembuatan keputusan ekonomi. Laporan keuangan juga menunjukkan hasil pertanggungjawaban manajemen atas penggunaan sumber daya yang dipercayakan kepada mereka (IAI, 2009).

Ashbaugh et al. (1999) mendefinisikan IFR sebagai suatu kondisi ketika suatu perusahaan menyediakan hal-hal berikut ini dalam website perusahaan: (1) satu set komprehensif laporan keuangan (termasuk footnote dan laporan auditor), (2) terdapat suatu link ke laporan tahunan, (3) terdapat link ke badan keuangan pemerintah. Hunter and Smith (2007) menjelaskan bahwa IFR merujuk pada penggunaan website perusahaan dalam menyebarkan informasi tentang performa keuangan perusahaan. Informasi keuangan yang disajikan dalam IFR mencakup laporan keuangan komprehensif, termasuk di dalamnya footnotes, bagian laporan keuangan, financial highlights dan ringkasan laporan keuangan (Ettredge et al., 2001; Oyelere et al., 2003; Chariri et al., 2005).

Sortur (2006) menjelaskan potensi penggunaan internet sebagai media pelaporan perusahaan berdasarkan keunggulan-keunggulan berikut ini: (1) Internet menawarkan solusi dengan biaya rendah (kepada pengguna dan penyedia) untuk mengakses data perusahaan dengan menggunakan jaringan yang sudah tersruktur sehingga dapat diakses dengan mudah. Perusahaan besar dapat menghilangkan biaya substansial untuk mencetak dan mengirimkan laporan tahunan; (2) Internet menawarkan akses secara instan (relatif terhadap versi cetakan) terhadap data tanpa batas waktu kepada pengguna; (3) Internet menyediakan media penyiaran ( komunikasi massa) untuk pelaporan perusahaan. Informasi dapat diakses oleh lebih banyak pengguna dibandingkan dengan batasan komunikasi secara tradisional. Tidak ada batas nasional karena jangkauan internet secara internasional. Internet juga dapat membantu akses potensial investor kepada perusahaan kecil; (4) Internet menawarkan potensi update informasi secara dinamis; (5) Mengurangi keterbatasan fleksibilitas presentasi daripada versi tradisional (paper-based); (6)Dapat mengakses data dengan volume yang lebih besar; (7) Fleksibilitas dalam model pengguna data yang diberikan. Meningkatkan jumlah dan tipe data yang diungkapkan serta merupakan suplementasi praktik pengungkapan tradisional; (9) Terdapat hypermedia dalam penyampaian data (menggunakan interlinking kapabilitas informasi World Wide Web; (10) Memungkinkan penggunaan grafik, kemampuan untuk mengunduh data, fasilitas press release, trend data dan analisis, fasilitas data yang dinamis, dan penyediaan pengukuran kinerja non-keuangan.

Telah banyak penelitian di berbagai negara yang meneliti hubungan antara ukuran perusahaan dengan IFR. Penelitian pertama dilakukan oleh Ashbaugh et al. (1999) di Amerika mengungkapkan bahwa ukuran perusahaan berpengaruh positif terhadap IFR. Hal ini konsisten dengan hasil penelitian Wagenhofer et al. (2003) yang mengambil sampel perusahaan di Austria dan Jerman. Studi yang dilakukan di Australia oleh Lymer and Debrerency (2003) menemukan bahwa ukuran perusahaan berpengaruh positif terhadap IFR. Penelitian terakhir yang dilakukan oleh Damaso et al. (2011) dengan objek studi perusahaan yang terdaftar di London Stock Exchange konsisten dengan hasil penelitian sebelumnya yang menemukan bahwa ukuran perusahaan berpengaruh positif terhadap IFR. Penelitian serupa yang dilakukan di Indonesia pun menunjukkan hasil yang konsisten bahwa ukuran perusahaan berpengaruh positif terhadap IFR (Prabowo, et al., 2005; Chariri, et al., 2005; Agustina, 2009; Almilia, 2009).

Berdasarkan hasil-hasil penelitian tersebut dapat dirumuskan hipotesis sebagai berikut: H1: Ukuran perusahaan berpengarù positif terhadap IFR

Penelitian yang dilakukan oleh Chariri et al. (2005) dan Agustina (2009) menemukan bahwa profitabilitas tidak berpengaruh terhadap IFR. Chariri et al. (2005) menyatakan bahwa perusahaan yang melakukan IFR maupun perusahaan non-IFR mengabaikan informasi mengenai profitabilitas dalam pelaporan keuangan melalui 
internet. Hasil penelitian tersebut tidak konsisten dengan penelitian Prabowo et al. (2005) yang mendapatkan hasil bahwa profitabilitas berpengaruh positif terhadap IFR. Perusahaan yang lebih baik secara keuangan membutuhkan alat yang tidak biasa untuk memberikan sinyal mengenai kondisi dan performa perusahaan. Penelitian selanjutnya yang dilakukan oleh Almilia (2009) menemukan hasil yang sama bahwa profitabilitas berpengaruh positif terhadap IFR. Hasil yang sama atas pengaruh profitabilitas terhadap IFR juga diungkapkan oleh penelitian Asbaugh et al. (1999) dan Pervan (2006) yang masing-masing melakukan penelitian di Amerika Serikat dan Kroasia

Berdasarkan hasil-hasil penelitian tersebut dapat dirumuskan hipotesis sebagai berikut: H2: Profitabilitas perusahaan berpengaruh positif terhadap IFR.

Chariri et al. (2005) menyatakan bahwa seiring dengan meningkatnya leverage, manajer dapat menggunakan IFR untuk membantu menyebarluaskan informasi-informasi positif perusahaan dalam rangka "mengaburkan" perhatian kreditur dan pemegang saham untuk tidak terlalu fokus hanya pada leverage perusahaan yang tinggi. Hal ini disebabkan pelaporan keuangan melalui internet dapat memuat informasi perusahaan yang lebih banyak dibandingkan melalui paper based reporting. Barnea et al. (1985) dalam Prabowo et al. (2005) menyatakan bahwa leverage mempunyai potensi untuk menimbulkan conflict of interest antara debt-holders dan shareholders, sedangkan debt-holders membawa agency cost. Melalui adanya hutang, pemegang saham dapat mendesak manajer untuk mengambil investasi yang berisiko tinggi dengan tujuan memperoleh laba atas investasi atau menyediakan excessive return kepada pemegang saham dengan mengesampingkan resiko kreditor. Hasil penelitian Chariri et al. (2005), menemukan bahwa leverage berpengaruh positif terhadap IFR. Hal ini tidak konsisten dengan penemuan Prabowo et al. (2005), Agustina (2009) dan Almilia (2009) yang mengungkapkan bahwa leverage tidak berpengaruh terhadap IFR.

Dengan demikian hipotesis yang diajukan adalah: H3: Leverage berpengaruh positif terhadap IFR.

Investor memberi nilai lebih kepada perusahaan yang lebih transparan, mengingat risiko yang ditanggung akan lebih kecil (Pervan, 2006). Hasil penelitian Pervan (2006) yang dilakukan di Slovenia serta Cormier, Ledoux dan Magnan (2009) menemukan bahwa PBV berpengaruh positif terhadap IFR. Akan tetapi hasil penelitian Pervan (2006) yang dilakukan di Kroasia menunjukkan bahwa PBV tidak berpengaruh terhadap IFR.

Dengan demikian, hipotesis yang diajukan adalah: H4: PBV berpengaruh positif terhadap IFR.

\section{Metode Penelitian}

Populasi yang digunakan dalam penelitian ini adalah seluruh perusahaan keuangan yang terdaftar di Bursa Efek Indonesia (BEI) pada tahun 2010. Pemilihan sampel dilakukan dengan menggunakan metode purposive sampling melalui kriteria tertentu yang telah ditetapkan sebelumnya. Kriteria sampel penelitian ini adalah sebagai berikut: 1) Perusahaan memiliki website; 2) Website perusahaan tidak dalam perbaikan atau maintenance; 3) Website perusahaan dapat diakses atau tidak error; 4) Perusahaan menampilkan informasi keuangan pada website perusahaan; 4) Perusahaan memiliki data PBV per 31 Desember 2010; dan 5) Perusahaan sampel mempunyai laporan keuangan auditan secara lengkap pada tahun 2010

Variabel penelitian ini menggunakan data dari sumber sekunder. Indeks IFR diperoleh dengan pengukuran dari website masing-masing perusahaan sampel. Periode akses website dilakukan pada bulan Februari 2012 dengan pertimbangan bahwa pada bulan tersebut merupakan masa up-to-date terkait dengan jadwal penelitian ini. Data untuk variabel independen diperoleh dari laporan keuangan auditan perusahaan sampel 
yang diperoleh dari situs BEI dan Indonesian Capital Market Directory (ICMD). Periode laporan keuangan (2010) dipilih karena merupakan laporan keuangan auditan terakhir yang diterbitkan saat penelitian ini dilakukan. Keabsahan data yang digunakan dalam penelitian ini sepenuhnya merupakan tanggung jawab lembaga yang bersangkutan. Teknik kepustakaan digunakan dalam menyusun telaah teori. Penelitian ini menggunakan buku, jurnal, dan artikel sebagai rujukan referensi atas materi yang dibutuhkan.

Penelitian ini menggunakan IFR sebagai variabel dependen dan empat variabel independen yaitu ukuran perusahaan, profitabilitas, leverage, dan PBV. Penerapan IFR diukur menggunakan indeks sesuai yang dilakukan oleh Almilia (2009). Ukuran perusahaan ditentukan dengan menggunakan logaritma dari total aset perusahaan. Profitabilitas diukur melalui ROA. Leverage diukur dengan debt to assets ratio (DAR). PBV diukur dengan nilai pasar ekuitas dibagi nilai buku pemegang saham.

Variabel dependen dalam penelitian ini adalah IFR yang diukur menggunakan indeks. Pengukuran indeks IFR dalam penelitian ini sama dengan teknik yang dipakai oleh penelitian Almilia (2009). Pengukuran indeks IFR ini merupakan teknik yang dikembangkan oleh Lymer et al. (1999) dan Cheng et al. (2000). Menurut Cheng et al. (2000) dalam Almilia (2009) indeks IFR dibagi menjadi empat komponen dan masingmasing komponen diberi bobot yang berbeda.

1. Isi/Content

Kategori isi/content ini diberi bobot $40 \%$. Isi atau content meliputi komponen informasi keuangan seperti laporan neraca, rugi laba, arus kas, perubahan posisi keuangan serta laporan keberlanjutan perusahaan. Informasi keuangan yang diungkapkan dalam bentuk html memiliki skor yang tinggi dibandingkan dengan format pdf, karena informasi dalam bentuk html lebih memudahkan pengguna informasi untuk mengakses informasi keuangan tersebut menjadi lebih cepat.

2. Ketepatwaktuan

Kategori ketepatwaktuan atau timeliness diberi bobot 20\%. Ketika perusahaan dapat menyajikan informasi yang tepat waktu, maka semakin tinggi indeksnya.

3. Pemanfaatan Teknologi

Kategori pemanfaaatan teknologi diberi bobot $20 \%$. Komponen ini terkait dengan pemanfaatan teknologi yang tidak dapat disediakan oleh media laporan cetak serta penggunaan media teknologi multimedia, analysis tools (contohnya, Excel's Pivot Table), fitur-fitur lanjutan (seperti implementasi "Intelligent Agent" atau XBRL).

4. User Support

Kategori user support diberi bobot $20 \%$. Indeks website perusahaan semakin tinggi jika perusahaan mengimplementasikan secara optimal semua sarana dalam website perusahaan seperti: media pencarian dan navigasi/search and navigation tools (seperti FAQ, links to homepage, site map, site search).

Ukuran perusahaan dapat diproksikan dari nilai kapitalisasi pasar, total aset, log penjualan, dan lain sebagainya (Ratnasari, 2010). Ukuran perusahaan dalam penelitian ini dihitung dengan rumus:

\section{Ukuran Perusahaan $=$ Log Total Aset}

Oyelere (2003) menyatakan bahwa variabel profitabilitas diukur dengan ROA (laba bersih setelah pajak/total aset). Hal ini disebabkan ROA memiliki tingkat yang lebih independen dalam mengukur profitablitas dibandingkan dengan ROE, sehingga profitabilitas akan dihitung dengan rumus sebagai berikut:

\section{ROA = Laba Bersih Setelah Pajak $\div$ Total Aset}

Damaso et al. (2011) megungkapkan bahwa leverage adalah jumlah hutang yang digunakan untuk mendanai aset perusahaan. Perusahaan dengan level leverage yang tinggi mempunyai lebih banyak financial cost, dan penyedia modal (debtholders) lebih 
memperhatikan kepentingannya di informasi keuangan. Leverage akan dihitung menggunakan rumus berikut ini:

\section{Leverage $=$ Total Hutang $\div$ Total Aset}

Sesuai dengan penelitian terdahulu, yaitu Pervan (2006) dan Cormier et al. (2009), PBV diukur menggunakan rumus sebagai berikut:

\section{PBV $=$ Nilai pasar ekuitas $\div$ Nilai buku pemegang saham}

Metode analisis yang digunakan dalam penelitian ini sesuai dengan penelitian Almilia (2009), yaitu menggunakan regresi ordinary least square (OLS) untuk melihat pengaruh variabel independen terhadap IFR. Persamaan regresi OLS dalam penelitian ini adalah:

$$
\mathrm{IFR}=\beta 0+\beta 1 \mathrm{SIZE}+\beta 2 \mathrm{ROA}+\beta 3 \mathrm{DAR}+\beta 4 \mathrm{PBV}+\beta 5 \mathrm{BOARD}+\varepsilon
$$

Keterangan:

$$
\begin{array}{ll}
\text { IFR } & \text { = indeks IFR } \\
\text { SIZE } & =\text { logaritma total aset } \\
\text { ROA } & \text { rasio laba bersih dibagi dengan total aset } \\
\text { DAR } & \text { = rasio total hutang dibagi dengan total aset } \\
\text { PBV } & \text { = nilai pasar ekuitas dibagi nilai buku pemegang saham } \\
\text { BOARD } & =\text { jumlah anggota dewan direksi } \\
\varepsilon & =\text { residual }
\end{array}
$$

\section{Model Penelitian}

Kerangka pikiran merupakan bagan sistemastis yang menggambarkan hubungan antar variabel penelitian. Berdasarkan uraian yang telah dijelaskan sebelumnya, kerangka pemikiran dapat diilustrasikan pada gambar berikut:

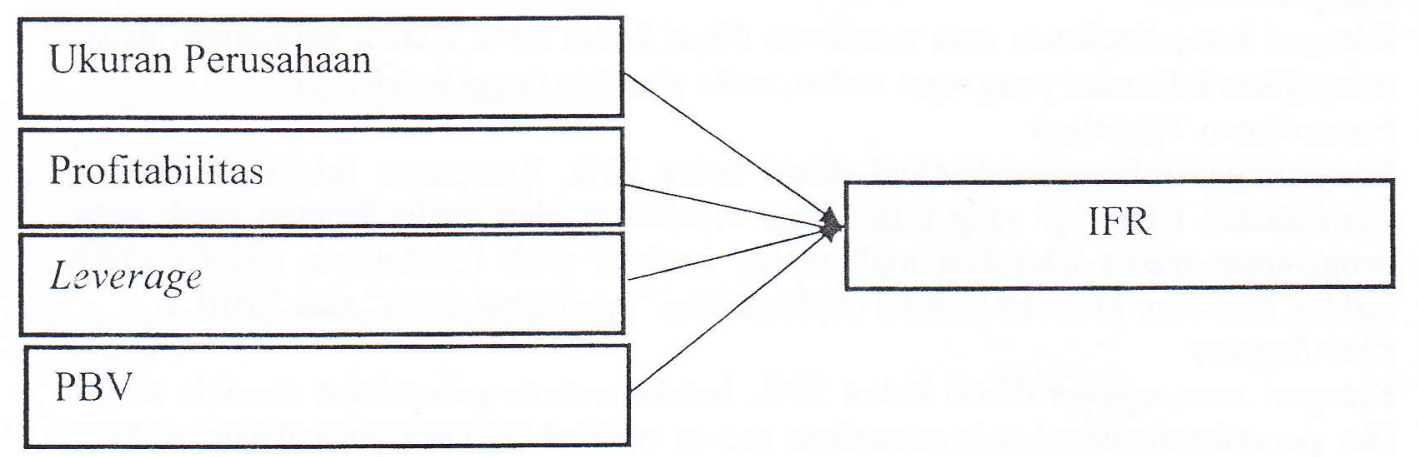

\section{Gambar 1. Model Penelitian}

\section{Hasil Penelitian dan Pembahasan}

Populasi dalam penelitian ini adalah seluruh perusahaan sektor keuangan yang terdaftar di Bursa Efek Indonesia pada tahun 2010. Sampel yang dipilih terbatas pada perusahaan yang menerapkan IFR pada website perusahaan. Jumlah sampel yang digunakan dipilih dengan metode purposive sampling, yang menghasilkan 43 perusahaan yang dapat dijadikan sebagai sampel dari total keseluruhan sebesar 71 perusahaan. Perincian total sampel terpilih dapat dilihat pada tabel 4.1 berikut. 
Tabel 1. Pemilihan Sampel Penelitian

\begin{tabular}{lll}
\hline No & \multicolumn{1}{c}{ Kriteria } & Jumlah \\
\hline 1 & Total perusahaan sektor keuangan yang terdaftar di BEI & 71 \\
\hline 2 & Total perusahaan keuangan yang tidak mempunyai website & $(9)$ \\
\hline 3 & Total website perusahaan yang error & $(6)$ \\
\hline 4 & Total website perusahaan yang under construction & $(1)$ \\
\hline 5 & $\begin{array}{l}\text { Total perusahaan yang tidak menampilkan informasi keuangan } \\
\text { di website }\end{array}$ & \\
\hline 6 & $\begin{array}{l}\text { Total perusahaan yang tidak tersedia data PBV per } \\
\text { Desember 2010 }\end{array}$ & $(0)$ \\
\hline 7 & $\begin{array}{l}\text { Total perusahaan yang tidak mempunyai laporan auditan } \\
\text { keuangan secara lengkap }\end{array}$ & $(0)$ \\
\hline
\end{tabular}

Sumber: Indonesian Capital Market Directory, laporan keuangan perusahaan, website perusahaan, dan hasil perhitungan menggunakan Ms. Excel 2007

Sampel terpilih merupakan perusahaan-perusahaan yang berasal dari industri yang berbeda-beda. Kategori industri didasarkan pada kategori Jasica Index, yang membagi perusahaan sektor keuangan menjadi empat kategori yaitu bank, institusi keuangan, asuransi, perusahaan sekuritas, dan other. Jenis industri yang paling banyak menjadi objek penelitian adalah jenis industri perbankan dengan 29 perusahaan. Sedangkan dari industri institusi keuangan terdapat dua perusahaan, industri sekuritas terdapat empat perusahaan, industri asuransi terdapat lima perusahaan, dan industri keuangan lain terdapat dua perusahaan.

\section{Statistik deskriptif}

Hasil statistik deskriptif dari penelitian ini disajikan pada Tabel 2. berikut ini: Tabel 2. Tabel Statistik Deskriptif

\begin{tabular}{lrrrrr}
\hline & N & Minimum & Maximum & \multicolumn{1}{c}{ Mean } & Std. Deviation \\
\hline SIZE & 43 & 11.10226 & 14.65299 & 12.92522 & .91235 \\
\hline ROA & 43 & -.05677 & .16972 & .02572 & .03353 \\
\hline DAR & 43 & .21374 & .93910 & .78494 & .18851 \\
\hline PBV & 43 & .25 & 6.07 & 1.98209 & 1.22392 \\
\hline IFR & 43 & 25.00 & 65.00000 & 41.66279 & 9.89331 \\
\hline \multicolumn{7}{r}{ Sumber: Lampiran 3 } & & &
\end{tabular}

Dari Tabel 2. diketahui bahwa model penelitian yang digunakan dalam penelitian ini memiliki variabel dependen IFR dengan nilai rata-rata sebesar 41,66279 dan standar deviasi sebesar 9,89331. Nilai standar deviasi yang lebih kecil dari nilai rata-rata menunjukkan bahwa indeks IFR yang dimiliki oleh masing-masing perusahaan sampel memiliki besaran yang hampir sama. Nilai maksimum dimiliki oleh PT Bank Mandiri (Persero) Tbk yaitu sebesar 65 sedangkan nilai minimum dimiliki oleh PT Bank Pundi Indonesia Tbk yang memiliki indeks IFR sebesar 25.

Variabel independen ukuran perusahaan memiliki rata-rata sebesar 12,9252 dan standar deviasi 0,91235. Nilai standar deviasi yang lebih kecil dari nilai rata-rata menunjukkan bahwa ukuran perusahaan sampel memiliki besaran yang hampir sama. Ukuran perusahan terbesar dimiliki oleh PT Bank Mandiri (Persero) Tbk yaitu sebesar 14,65299 sedangkan ukuran perusahaan terkecil dimiliki oleh Asuransi Harta Aman Pratama Tbk dengan nilai logaritma total aset sebesar 11,10226. 
Variabel profitabilitas memiliki rata-rata sebesar 0,02572 dan standar deviasi sebesar 0,03353. Nilai standar deviasi yang lebih besar daripada nilai rata-rata menunjukkan bahwa nilai profitabilitas perusahaan sampel memiliki perbedaan yang relatif besar. Hal ini disebabkan karena terdapat profitabilitas yagn bernilai negatif pada salah satu perusahaan sampel. Profitabilitas terbesar diraih oleh Panin Sekuritas yaitu sebesar 0,16972 sedangkan profitabilitas terkecil dimiliki oleh PT Bank Pundi Indonesia Tbk dengan nilai ROA sebesar $-0,05677$.

Selanjutnya variabel leverage memiliki rata-rata 0,78494 dan standar deviasi sebesar 0,18851 . Nilai standar deviasi yang lebih kecil dari nilai rata-rata menunjukkan bahwa leverage perusahaan sampel memiliki besaran yang hampir sama. Nilai maksimum leverage dimiliki oleh PT Bank Bukopin Tbk yaitu sebesar 0,93910, sedangkan nilai minimum dimiliki Lippo General Insurance Tbk dengan nilai DAR sebesar 0,21374.

Untuk variabel PBV memiliki rata-rata sebesar 1,9821 dan standar deviasi sebesar 1,22392. Nilai standar deviasi yang lebih kecil dari nilai rata-rata menunjukkan bahwa nilai PBV perusahaan sampel memiliki besaran yang hampir sama. Nilai PBV tertinggi dimiliki oleh PT Bank Internasional Indonesia Tbk yaitu sebesar 6,07 sedangkan nilai PBV terendah sebesar 0,25 dimiliki oleh Lippo General Insurance Tbk.

Untuk menguji normalitas data, dalam penelitian ini menggunakan uji normalitas menggunakan EViews.

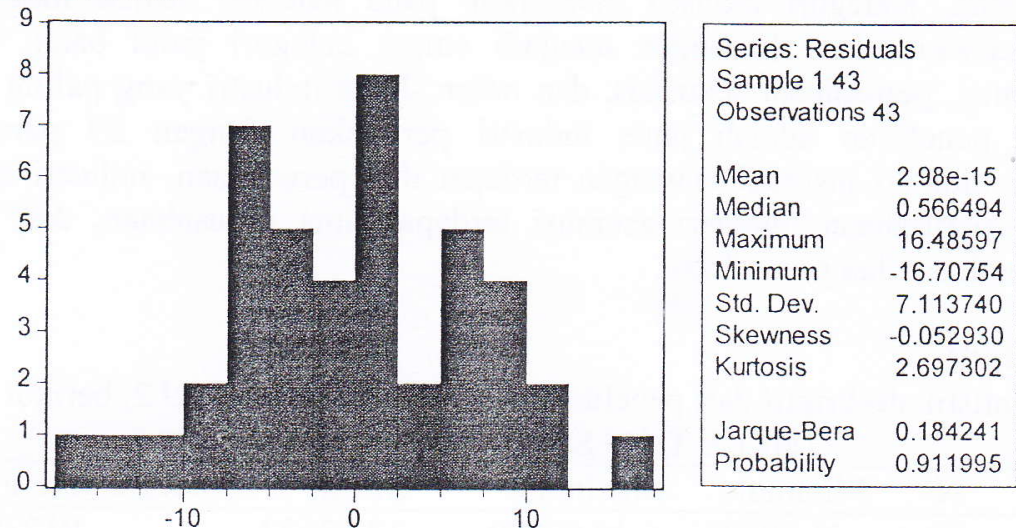

Gambar 2. Hasil Uji Normalitas

Berdasarkan analisis hasil normalitas data menggunakan Eviews di atas, terlihat bahwa nilai probabilitas sebesar $0.912>0.05$ maka dapat disimpulkan bahwa residualnya berdistribusi normal.

Berikut ini merupakan hasil uji white heteroscedasticity model regresi penelitian ini dengan menggunakan Eviews:

Tabel 3. Hasil Uji Heteroskedastisitas

White Heteroskedasticity Test:

\begin{tabular}{llll}
\hline \hline F-statistic & 0.473369 & Prob. F(8,34) & 0.866261 \\
Obs*R-squared & 4.309394 & Prob. Chi-Square(8) & 0.828186 \\
\hline \hline
\end{tabular}

Berdasarkan hasil uji White di atas tampak bahwa nilai $\mathrm{p}$-value dari Obs*Rsquared sebesar 0.828 (Obs*R-squared $>\alpha$ ), sehingga dapat disimpulkan bahwa tidak terjadi heteroskedastisitas.

Berdasarkan hasil pengolahan data statistik diperoleh tabel pengujian multikolinearitas sebagai berikut: 
Tabel 4. Hasil Uji Multikolinearitas

\begin{tabular}{ccccc}
\hline & SIZE & ROA & \multicolumn{1}{c}{ PBV } & \multicolumn{1}{c}{ DAR } \\
\hline SIZE & 1.000000 & -0.318384 & 0.570085 & 0.606659 \\
\hline ROA & -0.318384 & 1.000000 & -0.329453 & -0.634394 \\
\hline PBV & 0.570085 & -0.329453 & 1.000000 & 0.520758 \\
\hline DAR & 0.606659 & -0.634394 & 0.520758 & 1.000000 \\
\hline
\end{tabular}

Sumber: Lampiran 4

Dari tabel di atas terlihat bahwa semua nilai hubungan korelasi kurang dari 0.8 , sehingga dapat disimpulkan bahwa tidak ada hubungan antar variabel independen dalam penelitian ini.

Berdasarkan hasil perhitungan Eviews yang dapat dilihat pada tabel 4.6, nilai Adjusted $\mathrm{R}^{2}$ sebesar 42,9\%. Nilai ini menjelaskan bahwa variabel independen dalam penelitian ini dapat menjelaskan sebesar $42,9 \%$ atas perubahan yang terjadi pada indeks IFR perusahaan sektor keuangan yang terdaftar di BEI tahun 2010. Sedangkan sebesar $57,1 \%$ perubahan yang terjadi pada indeks IFR dijelaskan oleh variabel lain atau sebab lain di luar model yang digunakan dalam penelitian ini.

Selanjutnya adalah menentukan persamaan regresi dan melihat signifikansi pengaruh variabel independen terhadap variabel dependen. Model pengujian yang dilakukan dalam penelitian ini adalah sebagai berikut:

Keterangan:

$$
\text { IFR }=\alpha 1+\beta 0+\beta 1 \mathrm{SIZE}+\beta 2 \mathrm{ROA}+\beta 3 \mathrm{DAR}+\beta 4 \mathrm{PBV}+\beta 5 \mathrm{BOARD}+\varepsilon
$$

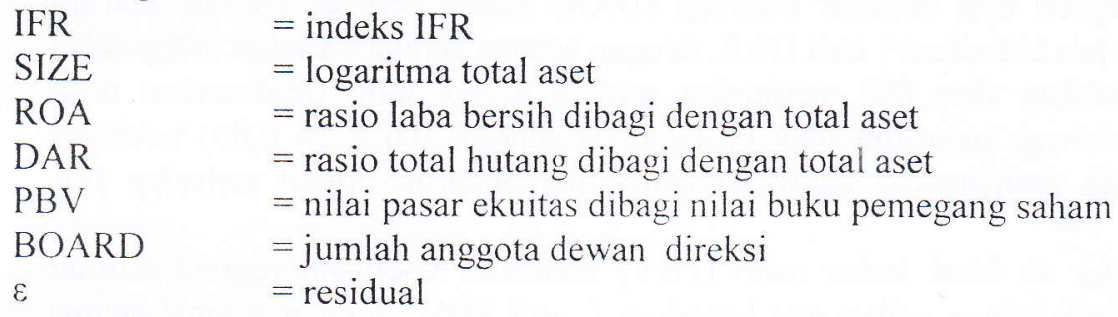

Tabel 5. Hasil Analisis Regresi Berganda

\begin{tabular}{llllr}
\hline Variable & Hip & Coefficient & t-stat & sig. \\
\hline Constant & \multicolumn{5}{c}{-55.77568} & -2.873198 & 0.0066 \\
\hline SIZE & $(+)$ & 7.014811 & 4.060316 & $0.0002^{*}$ \\
\hline ROA & $(+)$ & 72.84810 & 1.625316 & 0.1124 \\
\hline DAR & $(+)$ & 4.739849 & 0.489224 & 0.6275 \\
\hline PBV & $(+)$ & 0.593254 & 0.497610 & 0.6216 \\
\hline$N$ & 43 & & \\
\hline$R^{2}$ & 0.482974 & \\
\hline Adjusted R ${ }^{2}$ & 0.428550 & \\
\hline F. Statistic & 8.874312 & \\
\hline Prob. F-stat & 0.000037 & \\
\hline Variable Dependen & IFR $=$ Internet Financial Reporting & \\
\hline Variable Independen & & & \\
\hline SIZE = Ukuran Perusahaan & & \\
\hline ROA = Profitabilitas & & & \\
\hline DAR = Leverage &
\end{tabular}




\begin{tabular}{l} 
PBV $=$ Price to Book Value \\
\hline *Signifikansi pada tingkat keyakinan $5 \%$ \\
Sumber: Lampiran 5
\end{tabular}

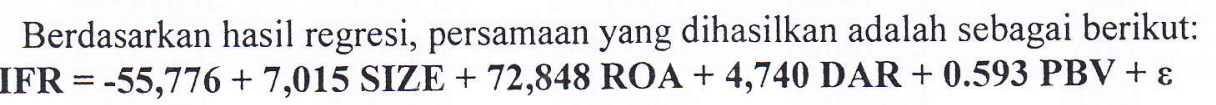

Nilai konstanta sebesar $-55,776$ menunjukkan bahwa nilai IFR negatif tanpa dipengaruhi oleh variabel ukuran perusahaan, profitabilitas, leverage, dan PBV. Koefisien regresi dari variabel ukuran perusahaan (SIZE) sebesar $+7,015$ yang berarti bahwa setiap kenaikan 1 unit ukuran perusahaan, yang diproksikan melalui logaritma total aset, akan meningkatkan skor IFR sebanyak 7,015 poin. Hal ini sesuai dengan hipotesis pertama penelitian ini yang menyatakan bahwa ukuran perusahaan berpengaruh positif terhadap IFR. Hal ini didukung dengan hasil statistik yang menunjukkan bahwa nilai probabilitas ukuran perusahaan sebesar $0,0002(<0,05)$. Dengan demikian hipotesis pertama penelitian ini diterima.

Variabel profitabilitas (ROA) memiliki koefisien regresi sebesar $+72,848$. Hal ini berarti bahwa setiap ada kenaikan 1 unit ROA dengan asumsi semua variabel independen tetap, akan menyebabkan skor IFR meningkat sebesar 72,848 poin. Hasil statistik menunjukkan nilai probabilitas variabel profitabilitas adalah sebesar $0,112(>0,05)$ sehingga hipotesis kedua penelitian yang menyatakan bahwa profitabilitas berpengaruh terhadap IFR ditolak.

Koefisien regresi dari variabel leverage (DAR) adalah sebesar $+4,740$. Hal ini berarti bahwa setiap ada kenaikan 1 unit DAR, dengan asumsi semua variabel independen tetap, akan menyebabkan skor IFR meningkat sebesar 4,740 poin. Berdasarkan hasil statistik, variabel leverage memiliki nilai probabilitas sebesar $0,628(>0,05)$ sehingga hipotesis ketiga yang menyatakan bahwa leverage berpengaruh positif terhadap IFR ditolak.

Variabel price to book value ratio (PBV) memiliki koefisien regresi sebesar $+0,593$. Hal ini berarti bahwa setiap ada kenaikan 1 unit PBV, dengan asumsi semua variabel independen tetap, akan menyebabkan skor IFR meningkat sebesar 0,593 poin. Hasil statistik menunjukkan nilai probabilitas variabel profitabilitas adalah sebesar 0,621 $(>0,05)$ sehingga hipotesis keempat penelitian yang menyatakan bahwa PBV berpengaruh positif terhadap IFR ditolak.

\section{Pengaruh ukuran perusahaan terhadap IFR}

Hasil pengujian hipotesis pertama membuktikan bahwa variabel ukuran perusahaan berpengaruh positif terhadap IFR. Hal ini searah dengan penelitian-peneltian sebelumnya seperti Asbaugh (1999), Wagenhofer (2003), Almilia (2008), dan Damaso et al. (2011). Penelitian-penelitian tersebut menyatakan bahwa ukuran perusahaan yang diproksikan dengan $\log$ total aset memiliki pengaruh positif terhadap IFR.

Hasil tersebut dapat dijelaskan dengan teori sinyal, teori agensi, dan analisis biaya manfaat, dimana terjadi kemungkinan adanya hubungan positif antara ukuran perusahaan dengan IFR (Agustina, 2009). Marston dan Polei (2004) menyatakan bahwa perusahaan besar cenderung diliput oleh media, mendapat tekanan komunitas dan politik. Melalui pengungkapan tambahan (dalam bentuk pengungkapan sukarela), perusahaan besar menyediakan informasi kepada pihak-pihak yang berkepentingan yang menunjukkan bahwa mereka telah "berbuat lebih dan dengan hasil yang baik", memberikan sinyal mengenai performa, keahlian, dan kredibilitas perusahaan mereka. 
Chariri et al. (2005) menyatakan bahwa perusahaan besar cenderung melakukan IFR dengan tujuan untuk mengurangi agency cost terkait dengan pencetakan dan pengiriman laporan keuangan. Hal ini didukung oleh Prabowo et al. (2005) yang menyatakan menyatakan bahwa perusahaan yang lebih besar cenderung menerapkan IFR karena benefit yang dihasilkan melebihi biaya yang dikeluarkan.

\section{Pengaruh profitabilitas terhadap IFR}

Hasil pengujian hipotesis kedua menyimpulkan bahwa profitabilitas tidak berpengaruh terhadap IFR. Hasil ini searah dengan penelitian Oyelere et al. (2003) dan Chariri et al. (2005). Alasan yang mendasari hasil penelitian ini adalah baik perusahaan yang melakukan IFR maupun perusahaan non-IFR mengabaikan informasi mengenai profitabilitas dalam pelaporan keuangan melalui internet (Chariri et al., 2005). Berdasarkan situs resmi Bank Indonesia, tingkat inflasi di Indonesia tahun 2010 mencapai $6.96 \%$. Hal ini mendorong meningkatnya beban operasional perusahaan karena adanya kecenderungan naiknya harga barang dan jasa yang mengakibatkan rendahnya profit yang didapatkan oleh perusahaan. Chariri et al. (2005) menejlaskan bahwa profitabilitas yang rendah tidak menghambat perusahaan untuk melakukan IFR. Baik perusahaan dengan profitabilitas tinggi maupun perusahaan dengan profitabilitas rendah akan tetap melakukan IFR dengan tujuan untuk menunjukkan keterbukaan manajemen perusahaan dalam melaporkan informasi keuangan perusahaan.

\section{Pengaruh leverage terhadap IFR}

Hasil pengujian hipotesis ketiga menunjukkan bahwa leverage tidak berpengaruh terhadap IFR. Dengan demikian hipotesis ketiga penelitian ini ditolak. Hasil penelitian ini searah dengan hasil penelitian Prabowo et al. (2005) dan Almilia (2009). Leverage tidak mempunyai pengaruh yang signifikan terhadap IFR pada perusahaan sektor keuangan yang terdaftar di BEI tahun 2010, hal ini terjadi karena mayoritas pemberi hutang lebih percaya kepada informasi yang didapatkan langsung dari perusahaan daripada indirect access seperti melalui IFR (Prabowo et al., 2005). Perusahaan yang memiliki tingkat leverage yang tinggi lebih cenderung untuk meminimalisasi biaya salah satunya adalah biaya untuk penerapan IFR yang bersifat sukarela. Hal ini dilakukan agar perusahaan dapat segera melunasi hutang kepada kreditur terlebih dahulu.

\section{Pengaruh PBV terhadap IFR}

Hasil pengujian hipotesis keempat menunjukkan bahwa PBV tidak berpengaruh terhadap IFR. Hasil penelitian ini tidak sesuai dengan penelitian Pervan (2006) dan Cormier et.al (2009). Hasil ini tidak sejalan dengan teori sinyal yang menyatakan bahwa semakin tinggi nilai PBV suatu perusahaan maka pengungkapan yang dilakukan akan semakin baik. Hal ini dimungkinkan karena tinggi rendahnya harga saham yang digunakan untuk menghitung nilai PBV tidak menggambarkan baik buruknya suatu perusahaan. Hal ini terkait dengan kondisi pasar modal Indonesia yang dikategorikan ke dalam pasar modal yang masih lemah.

Prabowo (2000) dalam Adhikara (2008) menjelaskan bahwa pasar modal Indonesia termasuk emerging market, yaitu pasar yang diindikasikan sebagai pasar modal yang masih lemah. Ciri pasar ini adalah: pertama, investor melakukan reaksi terhadap informasi secara lugu (naive) dan tidak canggih (unsophisticated). Investor mempunyai kemampuan terbatas dalam mengartikan, menganalisis, dan menginterpretasikan informasi yang mereka terima.

Oleh karena itu, investor cenderung menggunakan rumor, spekulatif, dan berperilaku mass behaviour. Sjahrir (1995) dalam Adhikara (2008) menyatakan bahwa 
investor yang bergabung dalam suatu massa, akan kehilangan rasionalitas kolektif, karena penentuan harga saham dalam komoditas perdagangan saham merupakan manifestasi dari faktor psikologis dan emosi investor. Hal inilah yang mengakibatkan nilai PBV tidak menjadi tolak ukur baik buruknya suatu perusahaan sektor keuangan yang terdaftar di BEI pada tahun 2010.

\section{Simpulan}

Berdasarkan hasil penelitian dapat diambil simpulan bahwa: 1) Ukuran perusahaan berpengaruh positif terhadap IFR pada perusahaan sektor keuangan yang terdaftar di BEI pada tahun 2010; 2) Profitabilitas tidak berpengaruh terhadap IFR pada perusahaan sektor keuangan yang terdaftar di BEI pada tahun 2010;3) Leverage tidak berpengaruh terhadap IFR pada perusahaan sektor keuangan yang terdaftar di BEI pada tahun 2010; dan 4) Price to book value tidak berpengaruh terhadap IFR pada perusahaan sektor keuangan yang terdaftar di BEI pada tahun 2010.

Penelitian ini hanya menggunakan sampel perusahaan sektor keuangan yang terdaftar di BEI pada tahun 2010 sehingga tidak dapat menggeneralisasi kondisi seluruh perusahaan di Indonesia. Berdasarkan pada keterbatasan penelitian tersebut, maka untuk penelitian selanjutnya dapat mengambil sampel seluruh perusahaan yang terdaftar di BEI dan menambahkan variabel lain, misalnya indeks corporate governance perusahaan.

\section{Daftar Pustaka}

Adhikara, MF Arrozi. 2008. Mental Accounting Investor di Bursa Efek Indonesia. Diakses dari http://www.esaunggul.ac.id/index.php?mib=prodi

$\&$ sid $=4 \&$ nav $=$ artikel.detail\&id $=89 \&$ title=Mental Accounting Investor di Bursa Efek Indonesia, 25 Maret 2012.

Agustina, Linda. 2009. Pengaruh Karakteristik Perusahaan terhadap Luas Pengungkapan Informasi Keuangan pada Website Perusahaan. Journal available at http:/leprints.undip.ac.id/8118.

Almilia, Luciana Spica. 2009. Determining Factors of Internet Financial Reporting in Indonesia. Accounting \& Taxation, Vol. 1, No.1, pp. 87-99. Published Working paper http://www.ssrn.com.

Asbaugh, H., K.M. Johnstone \& T.D. Warfield. 1999. Corporate Reporting on The Internet. Accounting Horizons 13, 1999, pp. 241-257.

Aziz, A.A., Ariffin, N. N. M. \& Mohamed, I. S. 2011. Internet Financial Reporting in Malaysia. International Conference on Machine Learning and Computing, Vol. 3.

Chariri, Anis \& Hanny Sri Lestari. 2005. Analisis Faktor -Faktor yang Mempengaruhi Pelaporan Keuangan di Internet (Internet Financial Reporting) dalam Website Perusahaan. Fakultas Ekonomi Universitas Diponegoro. Journal available at http//eprints.undip.ac.id/2398.

Cheng, A., Lawrence, S., \& Coy, D. 2000. Measuring the Quality of Corporate Financial Websites: A New Zealand Study. Paper presented at the meeting of the The 12th Asian-pacific Conference on International Accounting Issues, Beijing, China.

Damaso, G. \& Lourenco, I. C. 2011. Internet Financial Reporting: Environmental Impact Companies and Other Determinants. 8thInternational Conference on Enterprise Systems, Accounting and Logistics (8th ICESAL 2011) Greece.

Deller, D., Stubenrath, M., Weber, C. \& Wolfgang, J. 1999. A Survey on The Use of The Internet for Investor Relations in the USA, the UK and Germany. The European Accounting Review, Vol. 8, No.2, pp. 351-364. 
Ettredge, M., Richardson, V. J. \& Scholz, S. 2001. The presentation of financial information at corporate Web sites. International Journal of Accounting Information Systems, Vol. 2, No. 3, pp. 149-168.

Ettredge, M., Richardson, V. J. \& Scholz, S. 2002. Dissemination of information for investors at corporate Web sites. Journal of Accounting and Public Policy, Vol. 21, No. 4-5, pp. 357-369.

Ezat, A. \& El-Masry, A. 2008. The Impact of Corporate Governance on the Timeliness of Corporate Internet Reporting by Egyptian Listed Companies. Managerial Finance, Vol. 34, No. 2, pp. 848-867.

FASB. 2000. Business Reporting Research Project: Electronic Distribution of Business Information. Financial Accounting Standards Board, Norwalk, CT.

Ghozali, Imam. 2006. Aplikasi Analisis Multivariate dengan Program SPSS. Semarang: Badan Penerbit UNDIP.

Hanifa, M. H. \& Ab. Rashid, H. 2005. The Determinants of Voluntary Disclosures in Malaysia: The Case of Internet Financial Reporting. UNITAR E-Journal, 2(1), pp. $22-42$.

Hunter, S. dan L. M. Smith. 2007. Impact of Internet Financial Reporting on Emerging Markets. Journal of International Business Research; Forthcoming, available at http://papers.ssrn.com/sol3/papers.cfm?abstract id=1017078.

Ibrahim, Hadiasman. 2008. Pengaruh Tingkat Suku Bunga, Peringkat Obligasi, Ukuran Perusahaan dan DER terhadap Yield to Maturity Obligasi Korporasi di Bursa Efek Indonesia Periode Tahun 2004-2006, [Tesis]. Program Studi Magister Manajemen Universitas Diponegoro.

Ichmawati. Risya Ayu 2010. Pengaruh Peringkat Surat Hutang terhadap Yield Obligasi dengan Corporate Governance sebagai Variabel Pemoderasi, [Skripsi]. Fakultas Ekonomi Universitas Bakrie.

Ikatan Akuntan Indonesia 2009. Pernyataan Standar Akuntansi Keuangan No. 1 Tentang Penyajian Laporan keuangan. Dewan Standar Akuntansi Keuangan.

Lai, S., Lin ,C. \& Lee, H. C. 2007. An Empirical Study of The Impact of Internet Financial on Reporting Stock Prices. Working paper, available at :http://papers.ssrn.com/sol3/papers.cfm.

Lymer, Andrew . 1999. Special Section: The Internet and Corporate Reporting in Europe. European Accounting Review, Vol. 9, pp. 287-396.

Marston, C., \& Polei, A. 2004. Corporate Reporting on the Internet by German Companies. International Journal of Accounting Information Systems, 5,pp. 285311.

Moradi, M. Salehi, M. \& Arianpoor, A. 2011. A Study of The Reasons for Shortcomings in Establishment of Internet Financial Reporting in Iran. African Journal of Business Management, Vol. 5 (8), pp.3312-3321.

Oyelere, P., Fawzi, L. \& Richard, F. 2003. Determinants of Internet Financial Reporting by New Zealand Companies. Journal of International Financial Management and Accounting. 14: 1. pp. 26-63.

Pervan, Ivica. 2006. Voluntary Financial Reporting on the Internet- Analysis of the Practice of Stock-Market Listed Croatian and Slovene Joint Stock Companies. Financial Theory and Practice, 30 (1),pp. 1-27.

Prabowo, R. \& J. J. Carter Tambotoh. 2005. Internet Financial Reporting As A Voluntary Disclosure Practice: An Empirical Analysis Of Indonesian Manufacturing Firms Using Order Logit Regression. Jurnal Akuntansi \& Bisnis,Vol.5, No.2, pp 149160. 
Rahman, Z. D. 2011. The Impact of Internet Financial Reporting on Stock Prices Moderated by Corporate Governance: Evidence from Indonesia Capital Market. Published Working paper, available at http://www.ssrn.com.

Ratnasari, Ani. 2010. Pengaruh Karakteristik Perusahaan terhadap Pengungkapan Corporate Social Responsibility pada Perusahaan yang Tergabung dalam LQ-45, [Tesis]. Fakultas Ekonomi Universitas Indonesia.

Silva, W. M. \& L. A. Alves. 2004. The Voluntary Disclosure of Financial Information on the Internet and the Firm Value Effect in Companies across Latin America. 13th International Symposium on Ethics, Business and Society, available at: http://ssrn.com/ abstract $=493805$.

Silva W. M. \& T. E. Christensen. 2004. Determinants of Voluntary Disclosure of Financial Information On the Internet by Brazilian Firms. Working paper, available at http://ssrn.com/abstract $=638082$.

Sortur, Shrikant. (2006). Financial Reporting on Internet. The Chartered Accountant, pp. 996-1006.

Trabelsi, S., Labelle, R. \& Dumontier, P. 2008. Incremental Voluntary Disclosure on Corporate Websites, Determinants and Consequences. Journal of Contemporary Accounting \& Economics, Vol. 4, No. 2, pp. 120-155.

Trabelsi, S., Labelle, R. \& Laurin, C. 2004. The Management of Financial Disclosure on Corporate Websites: A Conceptual Model. Canadian Accounting Perspectives, Vol. 3, No. 2, pp. 235-259.

Turel, Asli. 2010. The Expectation Gap in Internet Financial Reporting: Evidence from an Emerging Capital Market. Middle Eastern Finance and Economics 8, pp. 94-107.

Xiao, J., Yang, H., \& Chow, C. 2004. The Determinants and Characteristics of Voluntary Internet-based Disclosures by Listed Chinese Companies. Journal of Accounting and Public Policy, 23,pp. 191-225.

Wagenhofer. 2003. Economic Consequences of Internet Financial Reporting. Schmalenbach Business Review, Vol 55. 